\title{
Leaf Essential Oil from Three Exotic Mytaceae Species Growing in the Botanical Garden of Rio de Janeiro, Brazil
}

\author{
Antonio C. Siani ${ }^{*}$, Marcos J. Nakamura ${ }^{1}$, Gabrielle P. das Neves ${ }^{1}$, Sérgio da S. Monteiro ${ }^{2}$, \\ Mônica Freiman S. Ramos ${ }^{3}$ \\ ${ }^{1}$ Departamento de Química de Produtos Naturais, Instituto de Tecnologia em Fármacos, Fundação Oswaldo \\ Cruz, Rio de Janeiro, Brazil \\ ${ }^{2}$ Fórum Itaboraí de Política, Ciência e Cultura na Saúde, Fundação Oswaldo Cruz, Palácio Itaboraí, Petrópolis, \\ Brazil \\ ${ }^{3}$ Departamento de Medicamentos, Faculdade de Farmácia, Faculdade de Farmácia, Universidade Federal do \\ Rio de Janeiro, CCS Bloco K, Cidade Universitária, Rio de Janeiro, Brazil \\ Email: "siani@far.fiocruz.br
}

Received 29 March 2016; accepted 22 April 2016; published 25 April 2016

Copyright (C) 2016 by authors and Scientific Research Publishing Inc.

This work is licensed under the Creative Commons Attribution International License (CC BY). http://creativecommons.org/licenses/by/4.0/

c) (7) Open Access

\section{Abstract}

The leaf essential oils of three Myrtaceae species: Melaleuca leucadendra, Lophostemon confertus and Ugni molinae, non-native to Brazil and growing in the Rio de Janeiro Botanical Garden, were obtained by hydrodistillation and analyzed by GC and GC-MS. Oil yields from fresh leaves were $0.76 \%, 0.08 \%$, and $0.04 \%$, respectively. Sixty-seven percent of $M$. leucadendra oil was made up of monoterpenes, wherein 1,8-cineole was largely predominant (49\%), followed by $\alpha$-terpineol (7.6\%) and terpinen-4-ol (4.3\%). The sesquiterpene profile was characterized by a significant amount of viridiflorol (29\%). Oil from $L$. confertus was $42 \%$ monoterpenes; the most predominant constituents being $\alpha$-pinene $(20.8 \%)$ and $\alpha$-thujene (7.1\%). Total sesquiterpenes $(55.4 \%)$ comprised spathulenol $(28 \%)$, globulol $(14 \%)$, and aromadendrene derivatives $(8.5 \%)$ as the main species. $U$. Molinae oil was exclusively composed of sesquiterpenes, with a predominance of $\beta$-elemene (44\%) followed by $\beta$-caryophyllene (7.1\%), and bicyclogermacrene (6.7\%); guaiol-type alcohols made up $30 \%$ of its profile. To the best of our knowledge, this is the first time $U$. Molinae leaf oil composition has been described. The composition of $M$. leucadendra oil corresponded to a chemotype described for a species growing in Cuba, but was different from that produced by $M$. leucadendra growing in Egypt, Tunisia, and elsewhere in Brazil. The profile of the L. confertus leaf oil showed high similarity with those described for Australian native specimens, in particular in relation to the relevant presence of $\alpha$-pinene, aromadendrenes, and the guaiol-type alcohols.

\footnotetext{
${ }^{*}$ Corresponding author.
}

How to cite this paper: Siani, A.C., Nakamura, M.J., das Neves, G.P., da S. Monteiro, S. and Ramos, M.F.S. (2016) Leaf Essential Oil from Three Exotic Mytaceae Species Growing in the Botanical Garden of Rio de Janeiro, Brazil. American Journal of Plant Sciences, 7, 834-840. http://dx.doi.org/10.4236/ajps.2016.76079 


\section{Keywords}

\section{Melaleuca leucadendra, Lophostemon confertus, Ugni molinae, Myrtaceae, Essential oil}

\section{Introduction}

The arboretum section of the Rio de Janeiro's Botanical Garden (BGRJ) comprises about 1500 species and almost 9000 specimens. Although the Brazilian flora is well represented, a large part of the collection constitutes non-native species [1]. For example, the collection includes some exotic species of Myrtaceae, a botanical family that characteristically accumulates volatile compounds in the leaves [2]. The goal of the present study was to assess the composition of leaf essential oil of three exotic species of Myrtaceae species growing in the BGRJ: Melaleuca leucadendra (L.), Lophostemon confertus Peter G. Wilson \& J. T. Waterh. (syn. Tristania conferta R.Br.), and Ugni molinae Turcz. The former two are woody-fruited species native to Australia, while the latter is native to Chile and is characterized by its production of pleasant tasting berries, as most South American Myrtaceae species are.

The Melaleuca genus comprises nearly 300 species, most of which are endemic to Australia [3]. Species of Melaleuca thrives in many kinds of environments, including swampy or temporarily inundated lands, poor or degraded soils [4]. Popularly known as tea tree, the leaves of these species produce an abundance of essential oils that possess medicinal properties and are useful as flavor ingredients in the food industries [5]-[7]. Melaleuca leucadendra (white paperbark; leucadendron, Greek for white tree) grows up to $40 \mathrm{~m}$ in height and has a thick trunk that may reach $1.5 \mathrm{~m}$ diameter in its original habitat [8]. This species is conspicuously distinguished by its white, very thin bark that much resembles sheets of paper. Three chemotypes have been identified for $M$. leucadendra based on the essential oil composition. They are characterized by a high content of eugenol-type phenylpropanoids [9] or terpenoids, of which $\gamma$-terpinene and terpinolene predominate among the monoterpenes [10]. Different chemotypes of the leaf essential oil have also been correlated with the geographical location of plants [5]. Under specific agroforest conditions and depending on the geographic locale, 1,8-cineole [11] or a combination of 1,8-cineole/ $\alpha$-terpineol/limonene [12] may be present and characterize the chemotype. Several parts of the plant $M$. leucadendra are traditionally used for their anti-parasitic, antiseptic, and insect repellent activities [13], and the leaf essential oil is used as an antifungal [14]. The 1,8-cineole chemotype (also containing $\alpha$-terpineol) of M. leucadendra leaf oil has been found to be active against Bacilus cereus and Staphylococcus aureus [15] and a series of four other fungi [16] while the methyl eugenol chemotype is an effective virucide against Herpes simplex virus type 1 [6]. Mild antioxidant and anti-hyaluronidase abilities have been observed for the former oil chemotype [16]. The ethanol extract from the branches of M. leucadendra is highly selective against Tripanosoma brucei [13]. The essential oil of M. leucadendra, pure or mixed with other oils, is ineffective in inducing mortality in Aedes, Anopheles, and Culex larvae [17], but significant irritant and repellent properties against Aedes aegypti females have been observed in experiments using the excito-repellency test chamber [18] [19]. An anti-feeding assay using gypsy moth larvae and the leaf ethanol extract of M. leucadendra led to the isolation of $(E, S)$-nerolidol as the active component [20].

Lophostemon confertus (Queensland brush box, Brisbane box) is a large to very large evergreen tree native to open forest and rainforest ecotones on the east coast of Australia that may reach 25 to $40 \mathrm{~m}$ in height [21] [22]. Due to its pest resilience, tolerance to pollution, and excellent shade-providing capacity, it has been used as street tree in the cities of various countries [23]. Leaves of L. confertus collected in Queensland have been shown to afford low yields of volatile oil that contained up to 33\% $\alpha$-pinene plus $20 \%$ limonene; with aromadendrene and spathulenol being relevant among the sesquiterpenes [22].

Ugni molinae is an evergreen shrub that is native to temperate rain forests in Chile (Chilean cranberry, Chilean guava, murtilla, uñi). Apart from exceptional cases, this species grows to around $2 \mathrm{~m}$ in height. It is cultivated as an ornamental shrub and produces an excellent berry suitable to use in jelly, jam, cakes, liqueurs, etc. [24] [25]. It was eventually introduced in some Pacific British colonies, and thereafter being popularized as the New Zealand cranberry. The leaves of $U$. molinae exhibit astringent and stimulant properties and have been used in folk medicine to treat several kinds of diarrhea [25]. Additionally, the leaves contain triterpenes that exhibit topical anti-inflammatory activity [26]. To the best of our knowledge, no reports exist describing the leaf volatile compounds of this species. 
This study aims to describe the composition of the essential oils from the three species non-native to Brazil: Melaleuca leucadendra, Lophostemon confertus and Ugni mollinae and compare them, where possible, with data reported for specimens growing elsewhere in the world.

\section{Material and Methods}

\subsection{Plant Material}

Melaleuca leucadendra (tree $23 \mathrm{~m}$ high, laminar white bark partially detached from the trunk), Lophostemon confertus (tree $24 \mathrm{~m}$ high, dark green leafy tree) and Ugni molinae (shruby tree, $4 \mathrm{~m}$ high) were collected in the Arboretum sections of the Botanical Garden of Rio de Janeiro (BGRJ), Brazil. L. Confertus was collected in August 2010; M. leucadendra and U. molinae were collected between March and May 2011. Voucher of M. leucadendra and $L$. confertus were deposited in the herbarium of the BGBJ under registrations RB 345845 and RB 343661, respectively. U. molinae was deposited in the plant collection of the Drug and Medicines Institute at Oswaldo Cruz Foundation, Rio de Janeiro, under code FFAR-424.

\subsection{Oil Isolation}

Fresh leaves $(0.7-1.0 \mathrm{Kg})$ of $M$. leucadendra, $L$. confertus and $U$. molinae were individually extracted by placing them with $3 \mathrm{~L}$ of water in a $12 \mathrm{~L}$ round-bottom flask coupled to a modified Clevenger apparatus and submitted to hydrodistillation for $4 \mathrm{~h}$. After the collection, the oils were centrifuged for 10 minutes at $5000 \mathrm{rpm}$ (Eppendorf model 5810 R, Hamburg, GE) and the residual water was carefully separated out. The oils were placed in amber sealed tubes and stored in the refrigerator. The yields $(\mathrm{w} / \mathrm{w})$ were calculated and the refractive indices were determined using a VEE GEE Model C10 Abbe refractometer (Nova-Tech International, Kingwood, USA).

\subsection{Gas Chromatographic Analysis}

The GC analysis of the oils was performed using an HP 6890N Network GC System gas chromatograph (Hewlett Packard, Palo Alto, CA) with flame ionization detection (GC-FID, injector at $250^{\circ} \mathrm{C}$ ) equipped with a capillary column HP-5 (30 m $\times 0.32 \mathrm{~mm} \times 0.25 \mu \mathrm{m}$ film thickness) with flow at $2.0 \mathrm{ml} / \mathrm{min} ; 1: 25$ split ratio mode. The oven temperature was programmed from $70^{\circ} \mathrm{C}$ (held for 5 minutes) to $290^{\circ} \mathrm{C}$ at $4{ }^{\circ} \mathrm{C} / \mathrm{min}$ and then held for 10 minutes. Helium was the carrier gas at an inlet pressure of 3.14 psi. The injection volume was $1 \mu \mathrm{L}$ of a 5 $\mathrm{mg} / \mathrm{ml}$ dichloromethane solution. The percentage compositions were obtained from relative peak areas by electronic integration using GC Station Rev. A.10.02 Agilent Technologies software (Santa Clara, USA). The GC-MS analyses were performed in a similar HP 6890N chromatograph equipped with a HP-5 MS column (30 $\mathrm{m} \times 0.32 \mathrm{~mm} \times 0.25 \mu \mathrm{m}$ film thickness) at the same conditions as above, excepting the gas flow at $0.5 \mathrm{ml} / \mathrm{min}$ and 1:20 split ratio mode. Data were processed using MSD Productivity ChemStation Software operating with ion source at $250^{\circ} \mathrm{C}$ and electron impact ionization at $70 \mathrm{eV}$. Individual components were identified by comparison of both mass spectra and GC retention data with those of authentic compounds stored in the Wiley library software 59943B or in the literature. The retention indices were calculated for all volatile constituents with reference to a homologue n-alkane series injected in the same analytical conditions [27].

\section{Results and Discussion}

\subsection{Melaleuca leucadendra}

The chemical constitutions of the three oils are displayed in Table 1. Earlier studies on the leaf essential oil compositions of Melaleuca species have highlighted the predominance of terpinene-type monoterpenes [28], with competitive biosynthetic routes leading to the accumulation of 1,8-cineole, $\alpha$-terpineol and limonene or terpinen-4-ol and $\gamma$-terpinene [29]. In the present study, the leaf oil yield from M. leucadendra was $0.76 \%(w / w)$, presenting $67 \%$ and $31 \%$ of identified monoterpenes and sesquiterpenes, respectively. The monoterpenes were primarily characterized by 1,8-cineole (49\%), $\alpha$-terpineol (7.6\%), and terpinen-4-ol $(4.3 \%)$ as well as lower amounts of limonene, $\alpha$-pinene, and $\beta$-pinene $(<3.4 \%)$. The sesquiterpenes were almost totally represented by viridiflorol (29\%). This oil profile is quite similar to that obtained by Pino et al. for M. leucadendra growing in Cuba [30]. On the other hand, the methyl eugenol-chemotype has been described for specimens growing else 
Table 1. Essential oil compositions of Melaleuca leucadendra, Lophostemon confertus and Ugni molinae.

\begin{tabular}{|c|c|c|c|c|}
\hline \multirow{3}{*}{ RI } & \multirow{3}{*}{ Compound } & \multicolumn{3}{|c|}{ Abundance (\%) } \\
\hline & & ML & LC & UM \\
\hline & & Ri 1.4770 & Ri 1.6350 & Ri 1.5070 \\
\hline 847 & E-hexanal & & $4.6 \pm 0.11$ & $1.2 \pm 0.01$ \\
\hline 922 & $\alpha$-thujene & & $7.1 \pm 0.26$ & \\
\hline 934 & $\alpha$-pinene & $3.38 \pm 0.06$ & $20.8 \pm 0.78$ & \\
\hline 980 & $\beta$-pinene & $1.7 \pm 0.03$ & $1.6 \pm 0.05$ & \\
\hline 989 & myrcene & & $3.4 \pm 0.09$ & \\
\hline 1031 & limonene & $1.4 \pm 0.01$ & $2.8 \pm 0.1$ & \\
\hline 1036 & 1,8-cineole & $48.7 \pm 0.54$ & & \\
\hline 1130 & $\alpha$-campholenal & & $1.5 \pm 0.02$ & \\
\hline 1184 & terpinen-4-ol & $4.3 \pm 0.03$ & & \\
\hline 1197 & $\alpha$-terpineol & $7.6 \pm 0.03$ & & \\
\hline 1334 & iso-dihydrocarveol acetate & & & $1.2 \pm 0.03$ \\
\hline 1384 & $\beta$-bourbonene & & & $2.2 \pm 0.02$ \\
\hline 1391 & $\beta$-elemene & & & $44.2 \pm 0.19$ \\
\hline 1423 & $\beta$-caryophyllene & & & $7.1 \pm 0.02$ \\
\hline 1441 & aromadendrene & & $6.1 \pm 0.06$ & $0.5 \pm 0.01$ \\
\hline 1459 & $\alpha$-humulene & & & $1.5 \pm 0.00$ \\
\hline 1463 & allo-aromadendrene & & $2.4 \pm 0.02$ & $0.9 \pm 0.00$ \\
\hline 1490 & $\beta$-selinene & & & $2.2 \pm 0.12$ \\
\hline 1485 & germacrene D & & & $1.1 \pm 0.01$ \\
\hline 1499 & byclogermacrene & & & $6.7 \pm 0.04$ \\
\hline 1531 & Z-nerolidol & & & \\
\hline 1567 & maaliol & & $1.7 \pm 0.01$ & $1.0 \pm 0.01$ \\
\hline 1581 & spathulenol & & $27.9 \pm 1.24$ & $7 \pm 0.04$ \\
\hline 1587 & caryophyllene oxide & $1.7 \pm 0.12$ & & \\
\hline 1591 & globulol & & $13.8 \pm 0.14$ & $8.4 \pm 0.04$ \\
\hline 1599 & viridiflorol & $27.8 \pm 0.75$ & $1.1 \pm 0.02$ & $2.4 \pm 0.01$ \\
\hline 1600 & ledol & $1.8 \pm 0.06$ & $2.4 \pm 0.03$ & \\
\hline 1629 & 10-epi- $\gamma$-eudesmol & & & $1.1 \pm 0.00$ \\
\hline 1636 & muurola-4,10(14)-dien-1- $\beta$-ol & & & $1.0 \pm 1.00$ \\
\hline 1649 & epi- $\alpha$-muurulol & & & $0.6 \pm 0.01$ \\
\hline 1661 & selin-11-en-4- $\alpha$-ol & & & $2.6 \pm 2.17$ \\
\hline 1664 & epi-neointermediol & & & $3.8 \pm 2.14$ \\
\hline \multirow[t]{8}{*}{1678} & 14-hydroxy-9-epi-(E)-caryophyllene & & & $0.4 \pm 0.00$ \\
\hline & hydrocarbon monoterpenes & 6.4 & 35.8 & 1.2 \\
\hline & oxygenated monoterpenes & 60.6 & 6.1 & 1.2 \\
\hline & Total monoterpenes & 67.0 & 41.9 & 2.4 \\
\hline & hydrocarbon sesquiterpenes & 0 & 8.6 & 67.2 \\
\hline & oxygenated sesquiterpenes & 31.3 & 46.9 & 30.2 \\
\hline & Total sesquiterpenes & & 55.5 & 97.4 \\
\hline & Total identified & 98.3 & 97.4 & 99.8 \\
\hline
\end{tabular}

$\mathrm{RI}=$ Retention index [27]. Ri = Refractive index. ML = Melaleuca leucadendra; $\mathrm{LC}=$ Lophostemon confertus; UM = Ugni molinae. Values of relative abundance were determined from the average of three injections in GC. 
where in Brazil [31] as well as in Australia [9]. The virtual absence of sesquiterpenes (or just traces at a maximum) characterizes the 1,8-cineole/ $\alpha$-terpineol/limonene chemotype of oils described for the species assigned to M. leucadendron cultivated in Egypt [6] and Java (plus $<10 \% \beta$-caryophyllene) [12], where the dry season favored the accumulation of 1,8-cineole [11]. Moreover, acyclic sesquiterpene E-nerolidol was described by Padalia et al. to accumulate in the leaf essential oil of M. leucadendra growing in India [32]; its accumulation was also reported in specimens assigned to M. leucadendron growing in Florida by Doskotch et al. [20], who studied the potential anti-feeding characteristics of the extracted compounds. In general, sesquiterpene alcohols (guaiol-, eudesmol- and cadinol-types) occur as minor or trace compounds in profiles reported for this species [9] [12] [16] [32].

\subsection{Lophostemon confertus}

The essential oil from Lophostemon confertus $(0.08 \% \mathrm{w} / \mathrm{w}$ for fresh material) yielded hydrocarbon and oxygenated sesquiterpenes in a 2:1 ratio. $\alpha$-Pinene (20.8\%) was predominant in the latter, followed by $\alpha$-thujene (7.1\%), small amounts of myrcene, limonene, and $\beta$-pinene. Spathulenol (28\%) and globulol (14\%) stood out among the $45 \%$ of guaiol-type alcohols that constituted the majority of sesquiterpene species. Aromadendrene derivatives (8.5\%) represented the second most prevalent group of sesquiterpenes in the oil. The low yield and the oil's main chemical composition showed good agreement with those reported for this species and others belonging to the genus Lophostemon, regarding the type of terpenoids present in plants growing in different locales in Australia [22].

\subsection{Ugni molinae}

Among the studied species, the leaves of Ugni molinae afforded the lowest yield (0.04\% $w / w$ on fresh material) of volatiles exclusively constituted by sesquiterpenes, in which $67 \%$ hydrocarbons and $30 \%$ alcohols (mostly of the guaiol-type) were identified. In the former group, there was a large predominance of $\beta$-elemene (44\%) followed by similar levels of $\beta$-caryophyllene (7.1\%) and bicyclogermacrene (6.7\%). No previously published data seem to be available on the leaf volatile compounds of $U$. molinae; the present study therefore constitutes the first to characterize Ugni molinae leaf oil. However, the related species U. myricoides Kunth O. Berg has been shown to be rich in $\alpha$-pinene (52\%) and 1,8-cineole (12\%), followed by caryophyllenes (9\%) and their respective oxides (up to 9\%) [33].

\section{Conclusion}

The present description of the volatile components in the leaves of $L$. confertus and $U$. molinae expands our knowledge of these Myrtaceae species. In the case of Melaleuca leaf oil, the chemotypes are especially important, given that they are employed in pharmaceuticals, cosmetics, disinfectants, deodorizers, and many other industrial aromatic products. Thus, as one of the most important ex-situ collections in Brazil, the living repository of native and exotic plants of the Botanical Garden of Rio de Janeiro not only contributes to aiding biodiversity conservation, but also enables the conduction of valuable technological studies.

\section{Acknowledgements}

The authors are thankful to Ricardo C. C. Reis, curator of the Living Collections Research Institute (BGRJ), for authorizing collections and to Luis C. Giordano and Josias B. da Silva for helping with the collections. We also thank to Arianne C. S. Vaucher for helping with the Refraction Index measurements. The GC analyses were supported by RPTPDTIS-FIOCRUZ.

\section{References}

[1] Jardim Botânico do Rio de Janeiro. Plantas do Arboreto. http://jbrj.gov.br/nosso-jardim/plantas

[2] Siani, A., et al. (2008) Monoterpenes and Sesquiterpenes of Neotropical Myrtaceae. In: Epifano, F., Ed., Current Trends in Phytochemistry, Research Signpost, Kerala, India, 223-251.

[3] Brophy, J.J., Craven, L.A. and Doran, J.C. (2013) Melaleucas: Their Botany, Essential Oils and Uses. Australian Centre for International Agricultural Research (ACIAR). 
[4] Brinkman, W. and Xuan, V.-T. (1991) Melaleuca leucadendron, a Useful and Versatile Tree for Acid Sulphate Soils and Some Other Poor Environments. International Tree Crops Journal, 6, 261-274.

http://dx.doi.org/10.1080/01435698.1991.9752891

[5] Southwell, I. and Lowe, R. (2003) Tea Tree: The Genus Melaleuca. CRC Press, Boca Raton, FL.

[6] Farag, R., et al. (2004) Chemical and Biological Evaluation of the Essential Oils of Different Melaleuca Species. Phytotherapy Research, 18, 30-35. http://dx.doi.org/10.1002/ptr.1348

[7] Hayouni, E.A., et al. (2008) Mechanism of Action of Melaleuca armillaris (Sol. Ex Gaertu) Sm. Essential Oil on Six LAB Strains as Assessed by Multiparametric Flow Cytometry and Automated Microtiter-Based Assay. Food Chemistry, 111, 707-718. http://dx.doi.org/10.1016/j.foodchem.2008.04.044

[8] Chong, C. (2008) A Riparian Perspective on Species Ecology and Evolution: Melaleuca leucadendra (Myrtaceae). James Cook University.

[9] Brophy, J.J. and Lassak, E.V. (1988) Melaleuca leucadendra L. Leaf Oil: Two Phenylpropanoid Chemotypes. Flavour and Fragrance Journal, 3, 43-46. http://dx.doi.org/10.1002/ffj.2730030109

[10] Brophy, J., Boland, D. and Lassak, E. (1989) Leaf Essential Oils of Melaleuca and Leptospermum Species from Tropical Australia. Trees for the Tropics: Growing Australian Multipurpose Trees and Shrubs in Developing Countries, Ch. 20, Canberra, 193-203.

[11] Ishii, H., Sunarto, S. and Kanazawa, Y. (2005) Variation in Kayu Putih (Melaleuca leucadendron LINN) Oil Quality under Different Farming Systems in Java, Indonesia. Eurasian Journal of Forest Research-Hokkaido University (Japan), 8, 15-20.

[12] Pujiarti, R., Ohtani, Y. and Ichiura, H. (2011) Physicochemical Properties and Chemical Compositions of Melaleuca leucadendron Leaf Oils Taken from the Plantations in Java, Indonesia. Journal of Wood Science, 57, 446-451. http://dx.doi.org/10.1007/s10086-011-1183-0

[13] Fernández-Calienes Valdés, A., et al. (2008) In Vitro Anti-Microbial Activity of the Cuban Medicinal Plants Simarouba glauca DC, Melaleuca leucadendron L and Artemisia absinthium L. Memórias do Instituto Oswaldo Cruz, 103, 615-618. http://dx.doi.org/10.1590/S0074-02762008000600019

[14] Bandaranayake, W.M. (2002) Bioactivities, Bioactive Compounds and Chemical Constituents of Mangrove Plants. Wetlands Ecology and Management, 10, 421-452. http://dx.doi.org/10.1023/A:1021397624349

[15] de Colmenares, N.G., et al. (1998) Phytoconstituents and Antimicrobial Activity of Melaleuca leucadendron Leaf Essential Oil from Venezuela. Ciencia, 6, No. 2.

[16] Pujiarti, R., Ohtani, Y. and Ichiura, H. (2012) Antioxidant, Anti-Hyaluronidase and Antifungal Activities of Melaleuca leucadendron Linn. Leaf Oils. Journal of Wood Science, 58, 429-436. http://dx.doi.org/10.1007/s10086-012-1270-x

[17] Amer, A. and Mehlhorn, H. (2006) Larvicidal Effects of Various Essential Oils against Aedes, Anopheles, and Culex Larvae (Diptera, Culicidae). Parasitology Research, 99, 466-472. http://dx.doi.org/10.1007/s00436-006-0182-3

[18] Noosidum, A., et al. (2008) Excito-Repellency Properties of Essential Oils from Melaleuca leucadendron L., Litsea cubeba (Lour.) Persoon, and Litsea salicifolia (Nees) on Aedes aegypti (L.) Mosquitoes. Journal of Vector Ecology, 33, 305-312. http://dx.doi.org/10.3376/1081-1710-33.2.305

[19] Noosidum, A., Chareonviriyaphap, T. and Chandrapatya, A. (2014) Synergistic Repellent and Irritant Effect of Combined Essential Oils on Aedes aegypti (L.) Mosquitoes. Journal of Vector Ecology, 39, 298-305. http://dx.doi.org/10.1111/jvec.12104

[20] Doskotch, R., et al. (1980) Nerolidol: An Antifeeding Sesquiterpene Alcohol for Gypsy Moth Larvae from Melaleuca leucadendron. Journal of Chemical Ecology, 6, 845-851. http://dx.doi.org/10.1007/BF00990408

[21] New South Wales Flora Online. Lophostemon confertus (R.Br.) Peter G. Wilson \& J.T. Waterh. http://plantnet.rbgsyd.nsw.gov.au/cgi-bin/NSWfl.pl?page=nswfl\&lvl=sp\&name=Lophostemon $\sim$ confertus

[22] Brophy, J.J., Goldsack, R.J. and Forster, P.I. (2000) Essential Oils of the Genus Lophostemon (Myrtaceae). Flavour and Fragrance Journal, 15, 17-20. http://dx.doi.org/10.1002/(SICI)1099-1026(200001/02)15:1<17::AID-FFJ859>3.0.CO;2-D

[23] Frank, S., et al. (2006) An Analysis of the Street Tree Population of Greater Melbourne at the Beginning of the 21st Century. Arboriculture and Urban Forestry, 32, 155.

[24] Scheuermann, E., et al. (2008) Evolution of Aroma Compounds of Murtilla Fruits (Ugni molinae Turcz) during Storage. Journal of the Science of Food and Agriculture, 88, 485-492. http://dx.doi.org/10.1002/jsfa.3111

[25] Schreckinger, M.E., et al. (2010) Berries from South America: A Comprehensive Review on Chemistry, Health Potential, and Commercialization. Journal of Medicinal Food, 13, 233-246. http://dx.doi.org/10.1089/jmf.2009.0233

[26] Aguirre, M.C., et al. (2006) Topical Anti-Inflammatory Activity of $2 \alpha$-Hydroxy Pentacyclic Triterpene Acids from the 
Leaves of Ugni molinae. Bioorganic \& Medicinal Chemistry, 14, 5673-5677. http://dx.doi.org/10.1016/j.bmc.2006.04.021

[27] Adams, R.P. (2007) Identification of Essential Oil Components by Gas Chromatography/Mass Spectrometry. Allured Publishing Corporation, Carol Stream, IL.

[28] Baker, R.T. and Smith, H.G. (1910) On the Australian Melaleucas and Their Essential Oils, Part III. Journal and Proceedings of the Royal Society of New South Wales, 44, 592-615.

[29] Southwell, I.A., Stiff, I.A. and Brophy, J.J. (1992) Terpinolene Varieties of Melaleuca. Journal of Essential Oil Research, 4, 363-367. http://dx.doi.org/10.1080/10412905.1992.9698086

[30] Pino, J.A., et al. (2010) Phytochemical Analysis and in Vitro Free-Radical-Scavenging Activities of the Essential Oils from Leaf and Fruit of Melaleuca leucadendra L. Chemistry \& Biodiversity, 7, 2281-2288. http://dx.doi.org/10.1002/cbdv.200900162

[31] Silva, C.J., et al. (2007) Comparative Study of the Essential Oils of Seven Melaleuca (Myrtaceae) Species Grown in Brazil. Flavour and Fragrance Journal, 22, 474-478. http://dx.doi.org/10.1002/ffj.1823

[32] Padalia, R.C., et al. (2015) The Essential Oil Composition of Melaleuca leucadendra L. Grown in India: A Novel Source of (E)-Nerolidol. Industrial Crops and Products, 69, 224-227. http://dx.doi.org/10.1016/j.indcrop.2015.02.019

[33] Quintão, N.L., et al. (2010) Chemical Composition and Evaluation of the Anti-Hypernociceptive Effect of the Essential Oil Extracted from the Leaves of Ugni myricoides on Inflammatory and Neuropathic Models of Pain in Mice. Planta Medica, 76, 1411-1418. http://dx.doi.org/10.1055/s-0029-1240891 